\title{
Sand Granules Ekstrak Biji Alpukat (Persea Americana Seed Extract) sebagai Larvasida Alami Pemberantas Demam Berdarah Dengue
}

\section{(Sand Granules of Avocado Seed Extract (Persea Americana Seed Extract) as Natural Larvaside of Dengue Fever)}

\author{
Fef Rukminingsih $^{{ }^{*}}$, Anasthasia Pujiastuti ${ }^{1}$ \\ I*Program Studi DIII Farmasi, Politeknik Katolik Mangunwijaya, Semarang, Indonesia. \\ E-mail: fefrukminingsih@gmail.com \\ Article Info: \\ Received: 5 September 2019 \\ in revised form: 6 Februari 2020 \\ Accepted: 25 Februari 2020 \\ Available Online: 02 Maret 2020 \\ Keywords: \\ Sand Granules \\ Avocado seed extract \\ Explotab \\ Larvacidal activity \\ Corresponding Author: \\ Fef Rukminingsih \\ Program Studi DIII Farmasi \\ Politeknik Katolik Mangunwijaya \\ Semarang \\ 50134 \\ Indonesia \\ email: fefrukminingsih@gmail.com

\begin{abstract}
Dengue hemorrhagic fever (DHF) threatens people in the rainy season. DHF is one of the major public health problems in Indonesia. These problems encourage an effort to eradicate Ae. aegypti larvae by using natural larvicide. One of the plants that can be used as natural larvicides is avocado seeds (Persea americana Seed) which contain saponin. This study aims to determine the larvacidal activity of avocado seed extract sandgranules with LC50 of 8.87 mg.mL-1 against Ae. aegypti larvae. This study is an experimental research with a complete random design in a unidirectional pattern. The independent variable in this study is the variation concentration of Explotab as a disintegrant agent ie 2, 3, and 4\%. Sand granules of avocado seed extract are made by wet granulation method. Results of the larvacidal activity test of avocado seed extract sand granules were analyzed by calculating the percentage of larvae mortality and statistical analysis using SPSS. The results showed that the larvicidal activity of pure avocado seed extract with LC50 $8.87 \mathrm{mg}$. L-1 is greater than the sand granules of avocado seed extract. The addition of Explotab did not affect the total larvae mortality.
\end{abstract}

Copyright $\odot 2019$ JFG-UNTAD

This open access article is distributed under a Creative Commons Attribution (CC-BY-NC-SA) 4.0 International license.

How to cite (APA $6^{\text {th }}$ Style):

Rukminingsih, F., Pujiastuti, A. (2020). Sand Granules Ekstrak Biji Alpukat (Persea Americana Seed Extract) Sebagai Larvasida Alami Pemberantas Demam Berdarah Dengue. Jurnal Farmasi Galenika :Galenika Journal of Pharmacy (eJournal), 6(1), 84-93. doi:10.22487/j24428744.2020.v6.i1.13607 


\section{ABSTRAK}

Penyakit demam berdarah dengue (DBD) menjadi salah satu ancaman masyarakat pada musim penghujan. Penyakit DBD sampai saat ini masih merupakan salah satu masalah kesehatan masyarakat yang utama di Indonesia. Permasalahan tersebut mendorong adanya usaha untuk memberantas larva Ae. aegypti dengan menggunakan larvasida alami. Salah satu tanaman yang dapat dimanfaatkan sebagai larvasida alami adalah biji alpukat (Persea americana Seed) yang mengandung saponin. Penelitian ini bertujuan untuk mengetahui daya larvasida sediaan sand granules ekstrak biji alpukat dengan $\mathrm{LC}_{50}$ sebesar $8,87 \mathrm{mg} \cdot \mathrm{mL}^{-1}$ terhadap larva Ae. aegypti. Penelitian ini termasuk jenis penelitian eksperimental dengan rancangan acak lengkap pola searah. Variabel bebas dalam penelitian ini adalah variasi konsentrasi Explotab sebagai bahan penghancur yaitu sebesar 2, 3, dan $4 \%$. Sand granules ekstrak biji alpukat dibuat dengan metode granulasi basah. Data hasil uji daya larvasida sand granules ekstrak biji alpukat di analisis dengan menghitung persentase mortalitas larva dan analisis statistik menggunakan SPSS. Hasil penelitian menunjukkan bahwa daya larvasida ekstrak biji alpukat murni dengan $\mathrm{LC}_{50} 8,87 \mathrm{mg} . \mathrm{L}^{-1}$ lebih besar dari sand granules ekstrak biji alpukat. Penambahan konsentrasi bahan penghancur Explotab dalam sand granules tidak berpengaruh terhadap total mortalitas larva.

Kata kunci: Sand Granules, Ekstrak Biji Buah Alpukat, Explotab, Daya Larvasida.

\section{PENDAHULUAN}

Penyakit demam berdarah dengue (DBD) menjadi salah satu ancaman masyarakat pada musim penghujan. Penyakit DBD sampai saat ini masih merupakan salah satu masalah kesehatan masyarakat yang utama di Indonesia, khususnya Provinsi Jawa Tengah. Hal ini terbukti dari 35 kabupaten/kota sudah pernah terjangkit DBD. Angka kesakitan/Incidence Rate (IR) di Provinsi Jawa Tengah pada tahun 2012 sebesar 19,29/100.000 penduduk, meningkat bila dibandingkan tahun 2011 (15,27/100.000 penduduk) (Kemenkes RI, 2018). Penyebab meningkatnya penyebaran penyakit DBD dan jumlah penderita DBD karena semakin meningkatnya arus transportasi penduduk dari satu daerah ke daerah lain. Vektor utama penyebar virus dengue penyebab DBD adalah nyamuk Ae. aegypti (Sembel, 2009). Manusia yang terinfeksi virus dengue digigit nyamuk Ae. aegypti maka virus dengue akan masuk bersama darah yang diisapnya. Di dalam tubuh nyamuk, virus dengue akan berkembangbiak dengan cara membelah diri dan menyebar diseluruh bagian tubuh nyamuk. Sebagian besar virus dengue berada dalam kelenjar liur nyamuk. Dalam waktu 1 minggu jumlah virus dengue dapat mencapai puluhan atau bahkan ratusan ribu yang siap untuk ditularkan atau dipindahkan pada manusia (Kemenkes RI, 2019).

Pemberantasan Ae. aegypti sebagai vektor utama DBD dapat dilakukan dengan berbagai cara antara lain dengan sanitasi lingkungan, yang bertujuan untuk mengurangi habitat larva, pemberantasan dengan menggunakan insektisida ditujukan pada nyamuk dewasa maupun larva (Sukowati, 2010). Pemberantasan vektor DBD menggunakan bahan kimia menyebabkan terjadinya peningkatan resistensi, pencemaran lingkungan, keracunan dan kematian hewan lain yang bukan sasaran (Widiarti et al., 2011). Permasalahan tersebut mendorong adanya usaha untuk menanggulangi larva Ae. aegypti dengan menggunakan larvasida alami. Salah satu tanaman yang dapat dimanfaatkan sebagai larvasida alami adalah biji alpukat (Persea americana Seed) yang mengandung saponin. Penelitian tentang daya larvasida ekstrak biji alpukat terhadap larva Ae. aegypti telah dilakukan dengan hasil Lethal Concentration $50\left(\mathrm{LC}_{50}\right)$ sebesar 8,87 mg. $\mathrm{L}^{-1}$ (Jaime, 2009). Oleh karena itu perlu dilakukan penelitian tentang bentuk sediaan ekstrak biji alpukat yang siap digunakan oleh masyarakat dengan kemampuan daya larvasida yang sama dengan ekstrak biji alpukat murni. Bentuk sediaan yang dapat dibuat yaitu sand granules yang mudah larut dalam air. Sand granules ekstrak biji alpukat dibuat dengan penambahan bahan penghancur Explotab atau Sodium Starch Glycolate (SSG) dan bahan pengisi Saccharum Lactis (Rowe, et al., 2009). Explotab merupakan superdisintegrant yang umumnya ditambahkan dalam sediaan farmasetik (Bhusnure, et al., 2015). Cara penambahan bahan penghancur dapat dilakukan sebelum granulasi maupun setelah granulasi atau kombinasi keduanya (Priyambodo, 2007). Pada formula yang mengandung bahan aktif berbentuk ekstrak kental dalam jumlah besar (> $30 \%$ ) maka tidak perlu ditambahkan bahan pengikat (Anief, 2000). Penelitian ini bertujuan untuk 
membuat sand granules ekstrak biji alpukat dengan $\mathrm{LC}_{50}$ sebesar $8,87 \mathrm{mg} \cdot \mathrm{mL}^{-1}$ yang memberikan daya larvasida terhadap larva Ae. Aegypti.

\section{METODE PENELITIAN}

Penelitian ini termasuk jenis penelitian eksperimental dengan rancangan acak lengkap pola searah. Variabel bebas dalam penelitian ini adalah variasi konsentrasi Explotab sebagai bahan penghancur sediaan sand granules yaitu $2 \%, 3 \%$, dan $4 \%$. Variabel tergantung dari penelitian ini adalah waktu larut sediaan sand granules dalam air dan jumlah mortalitas larva Ae. Aegypti.

\section{Alat dan Bahan}

Alat yang digunakan yaitu pisau, penjemur dari bambu yang berlubang-lubang, kain hitam, Soxlet, Erlenmeyer, pengaduk, Rotary vacuum evaporator, waterbath, beaker glass, pipet tetes, pencatat waktu, neraca digital, cawan porselen, ayakan mesh 16 dan mesh 18 serta alat fotografi. Bahan yang digunakan yaitu buah alpukat, larva Ae. aegypti instar IV, heksan pro analisis, air, Saccharum Lactis dan Explotab.

\section{Metode}

\section{Determinasi tanaman}

Determinasi tanaman alpukat dilakukan di Laboratorium Farmakognosi Fitokimia Prodi DIII Farmasi Politeknik Katolik Mangunwijaya dengan mencocokkan ciri-ciri tanaman dengan kunci determinasi.

\section{Pengumpulan dan pengeringan bahan}

Buah alpukat diperoleh dari pasar Johar Semarang. Buah yang telah terkumpul kemudian dibelah untuk memisahkan biji dari daging buahnya. Biji yang terkumpul dicuci bersih dengan air mengalir untuk menghilangkan kotoran-kotoran yang melekat pada biji. Biji yang telah bersih dipotong kecilkecil kemudian dihamparkan di atas penjemur yang berlubang dan dijemur di bawah sinar matahari langsung dengan ditutup kain hitam. Biji alpukat yang sudah kering kemudian dihaluskan dengan blender.

\section{Pembuatan ekstrak heksan}

Sebanyak 25 gram serbuk kering biji alpukat dimaserasi menggunakan pelarut heksan $250 \mathrm{~mL}$. Maserasi dilakukan selama 24 jam. Hasil maserasi yang telah terkumpul dipekatkan dengan Rotary vacuum evaporator dan waterbath sehingga diperoleh ekstrak pekat.

\section{Kolonisasi Nyamuk}

Larva Ae. aegypti instar IV yang digunakan diperoleh dari Balai Besar Penelitian dan Pengembangan Vektor dan Reservoir Penyakit Salatiga. Larva diperoleh dengan cara memelihara nyamuk dewasa sebagai induk di dalam kurungan yang terbuat dari kawat dilapisi dengan kasa atau kelambu. Nyamuk diberi makan dengan meletakkan kelinci di dalam kurungan. Mangkuk yang diisi air sepertiga bagian dan pada bagian dinding mangkuk di atas permukaan air dilapisi kertas saring dimasukkan juga dalam kurungan. Nyamuk akan bertelur dan telur tersebut menempel pada kertas saring. Kertas saring diangkat setiap 2-3 hari sekali dan dikeringkan pada suhu kamar. Telur yang akan ditetaskan dimasukkan dalam baki berisi air dan akan menetas dalam 1-3 hari. Larva hasil penetasan telur dipelihara dan diberi makan dog food, setelah 5-6 hari akan mencapai stadium III atau IV dan siap untuk penelitian (Widayanti, 2001). 


\section{Pembuatan Sand Granules}

Sand granules ekstrak biji alpukat dibuat dengan metode granulasi basah. Metode granulasi basah merupakan metode pembentukan granul dengan mencampurkan bahan aktif dengan bahan pengisi, yang akan bersatu dengan adanya bahan pengikat dengan pembawa air atau pelarut yang sesuai (Agoes, 2012). Formula sand granules ekstrak biji alpukat dapat dilihat pada Tabel 1.

Tabel 1. Formula Sand Granules Ekstrak Biji Alpukat

\begin{tabular}{lccc}
\hline \multirow{2}{*}{ Nama Bahan } & \multicolumn{3}{c}{ Jumlah Bahan (\%) } \\
\cline { 2 - 4 } & Formula I & Formula II & Formula III \\
\hline Ekstrak biji buah alpukat & 0,0887 & 0,0887 & 0,0887 \\
\hline Explotab & 2 & 3 & 4 \\
\hline Saccharum lactis & hingga 100 & hingga 100 & hingga 100 \\
\hline
\end{tabular}

Setiap formula dibuat dengan cara menambahkan Explotab dan Saccharum Lactis pada ekstrak heksan biji alpukat. Semua bahan diaduk sampai homogen dan terbentuk massa granul yang bagus. Massa granul basah yang sudah terbentuk kemudian diayak dengan mesh 16. Granul basah selanjutnya dikeringkan menggunakan oven. Granul yang sudah kering kemudian dilakukan pengayakan dengan mesh 18 (Agoes, 2012). Granul kering yang dihasilkan selanjutnya dilakukan pengemasan dan diuji daya larvasidanya. Setiap kemasan berisi $10 \mathrm{~g}$ sand granules yang mengandung ekstrak heksan biji alpukat sebesar $8,87 \mathrm{mg}$.

\section{Uji daya larvasida}

Uji daya larvasida dilakukan dengan 4 variasi perlakuan yaitu 1 kontrol positif dan 3 sand granules dengan variasi konsentrasi bahan penghancur. Perlakuan kontrol positif dilakukan dengan cara melarutkan ekstrak heksan biji alpukat pekat hasil penyarian dengan konsentrasi 8,87 mg.L $\mathrm{L}^{-1}$. Kontrol positif dibuat dengan mengambil 8,87 mg ekstrak pekat dan dimasukkan dalam beaker glass kemudian ditambah air ledeng $1000 \mathrm{~mL}$ dan 50 ekor larva Ae. aegypti instar IV (Pujiastuti et al., 2008).

Uji daya larvasida pada 3 perlakuan sand granules digunakan 3 beaker glass berisi $1000 \mathrm{~mL}$ air ledeng sebagai media uji. Pada setiap beaker glass ditambahkan 15 gram sand granules dengan 3 variasi konsentrasi bahan penghancur. Dihitung waktu yang dibutuhkan oleh tiap varian sand granules untuk melarut sempurna, yang ditunjukkan dengan tidak adanya butiran sand granules. Sand granules yang telah melarut, selanjutnya ditambahkan 50 ekor larva Ae. aegypti instar IV dalam setiap beaker glass (Pujiastuti et al., 2008).

Pengamatan terhadap mortalitas larva dilakukan setiap jam selama 6 jam berturut-turut kemudian dihitung total mortalitas larva setelah 24 jam. Pengujian dilakukan dengan pengulangan sebanyak 5 kali. Berdasarkan Pujiastuti (2003), persentase mortalitas larva dihitung dengan cara :

$\%$ mortalitas larva $=\frac{\text { jumlahmortalitas larva }}{\text { jumlahlarva }} \times 100 \%$ 


\section{Analisis Hasil}

Data hasil uji daya larvasida sand granules ekstrak biji alpukat di analisis dengan menghitung mortalitas larva dan analisis statistik menggunakan SPSS. Jika pada kelompok kontrol negatif terjadi mortalitas larva antara 5\% - 9\% maka dilakukan koreksi dengan formula "Abbot" untuk menentukan $\%$ mortalitas, dengan rumus :

$$
\% \text { mortalitas }=\frac{\% \text { mortalitas kelompok uji-\% mortalitas kelompok kontrol }}{100-\% \text { mortalitas kelompok kontrol }} \times 100 \%
$$

\section{HASIL DAN PEMBAHASAN}

Biji alpukat sebelum diekstraksi dilakukan perajangan dan pengeringan. Hasil dari proses perajangan dan pengeringan biji alpukat dapat dilihat pada gambar 1. Hasil organoleptis rajangan biji alpukat yang sudah kering yaitu berwarna hitam kecoklatan, berbau khas dan berasa pahit. Ekstraksi biji alpukat dengan metode maserasi, menghasilkan ekstrak kental. Organoleptis ekstrak biji alpukat yaitu memiliki konsistensi yang kental, berbau khas biji alpukat serta berwarna coklat bata. Hasil dari proses perajangan, pengeringan dan ekstrak biji alpukat dapat dilihat pada gambar 1.

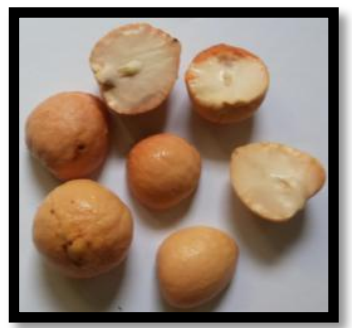

A

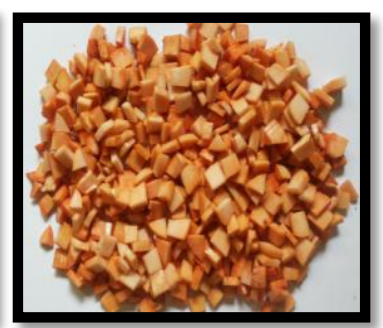

B

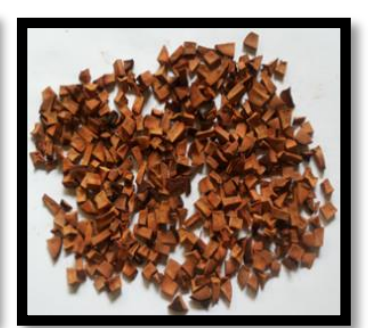

C

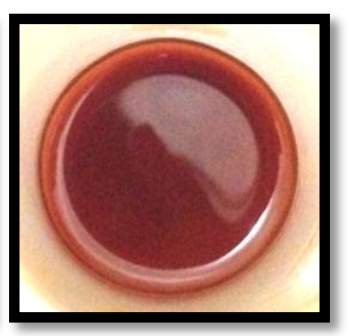

D

Gambar 1. Hasil Perajangan dan Ekstrak Biji Buah Alpukat (Persea americana Mill.)

\section{Keterangan :}

$\mathrm{A}=$ Biji buah alpukat

$\mathrm{B}=$ Irisan biji buah alpukat basah (sebelum dikeringkan)

$\mathrm{C}=$ Irisan biji buah alpukat kering (setelah dikeringkan)

$\mathrm{D}=$ Ekstrak kental biji alpukat

Sediaan sand granules ekstrak biji alpukat yang dihasilkan pada ketiga formula memiliki organoleptis yang sama yaitu berbentuk granul, berwarna putih dan tidak berbau. Hal ini berarti perbedaan konsentrasi Explotab tidak berpengaruh pada organoleptis sand granules. Sand granules formula I, II dan III dapat dilihat pada gambar 2. 


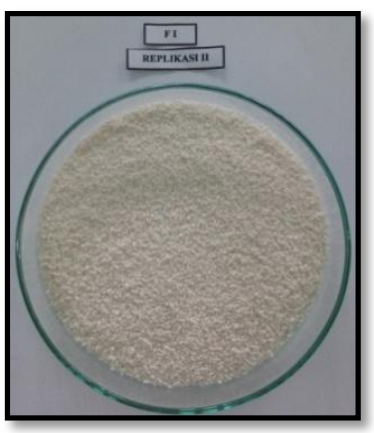

Formula I

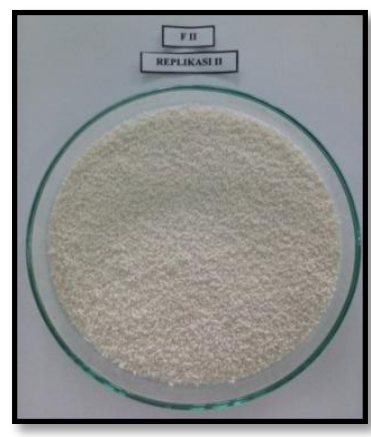

Formula II

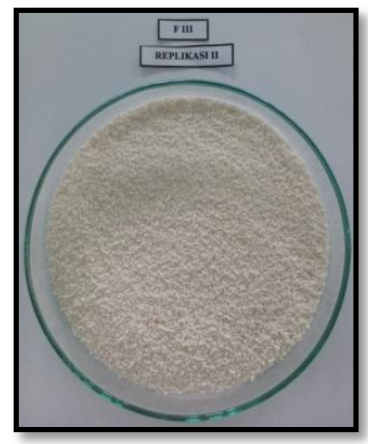

Formula III

Gambar 2. Sediaan Sand Granules Ekstrak Biji Buah Alpukat Formula I, II, dan III

Keterangan :

Formula I = konsentrasi explotab $2 \%$

Formula II = konsentrasi explotab $3 \%$

Formula III = konsentrasi explotab $4 \%$

Pengujian daya larvasida dilakukan dengan 4 perlakuan yaitu 1 perlakuan kontrol positif dan 3 perlakuan uji daya larvasida menggunakan sand granules. Hasil pengamatan jumlah larva yang mati pada uji daya larvasida sediaan sand granules ekstrak biji buah alpukat dapat dilihat pada Tabel 2.

Tabel 2. Hasil Mortalitas Larva pada Uji Daya Larvasida Sand Granules Ekstrak Biji Buah Alpukat

\begin{tabular}{cccccccccc}
\hline \multirow{2}{*}{ Perlakuan } & \multicolumn{8}{c}{ Rata-rata Jumlah Mortalitas Larva (ekor) } & \multirow{2}{*}{$\begin{array}{c}\text { total mortalitas } \\
\text { larva }\end{array}$} \\
\cline { 2 - 9 } & $\mathbf{1}$ jam & $\mathbf{2}$ jam & 3 jam & 4 jam & $\mathbf{5}$ jam & $\mathbf{6}$ jam & $\mathbf{2 4}$ jam & \\
\hline I & 0 & 0,33 & 2 & 4 & 6 & 4 & 7,67 & 24 \\
\hline II & 0 & 0 & 1,33 & 2,67 & 4,33 & 3 & 8 & 19,3 \\
\hline III & 0 & 0 & 1,67 & 2,33 & 3 & 4,67 & 8,33 & 20 \\
\hline IV & 0 & 0 & 1,67 & 3,33 & 3,33 & 4,33 & 8,33 & 21 \\
\hline
\end{tabular}

\section{Keterangan :}

I : Kontrol positif ekstrak heksan biji buah alpukat $8,87 \mathrm{mg} / \mathrm{L}$

II : Sediaan sand granules ekstrak biji buah alpukat formula I

III : Sediaan sand granules ekstrak biji buah alpukat formula II

IV : Sediaan sand granules ekstrak biji buah alpukat formula III

Analisis hasil uji daya larvasida dilakukan dengan menghitung persentase mortalitas larva dan analisis statistik menggunakan SPSS. Berdasarkan hasil pengamatan jumlah larva mati pada uji daya larvasida, nilai persentase mortalitas larva dapat dilihat pada Tabel 3. 
Tabel 3. Mortalitas Larva Pada Uji Daya Larvasida Sand Granules Ekstrak Biji Buah Alpukat

\begin{tabular}{ccccc}
\hline Perlakuan & $\begin{array}{c}\text { Jumlah larva mati } \\
\text { dalam 24 jam (ekor) }\end{array}$ & $\begin{array}{c}\text { Persentase } \\
\text { kematian (\%) }\end{array}$ & $\begin{array}{c}\text { Nilai } \\
\text { Normalitas }\end{array}$ & p-value \\
\hline I & 24 & 48,00 & 1,000 & \\
\cline { 1 - 4 } II & 19,33 & 38,66 & 0,00 & \multirow{2}{*}{$0,041^{\text {a }}$} \\
\cline { 1 - 4 } III & 20 & 40,00 & 1,000 & \\
\hline IV & 21 & 42,00 & 1,000 & \\
\cline { 1 - 3 }
\end{tabular}

Keterangan :

${ }^{\mathrm{a}}$ Kruskal Wallis Test

I $\quad$ : Kontrol positif ekstrak heksan biji buah alpukat $8,87 \mathrm{mg} / \mathrm{L}$

II $\quad$ : Sediaan sand granules ekstrak biji buah alpukat formula I

III : Sediaan sand granules ekstrak biji buah alpukat formula II

IV : Sediaan sand granules ekstrak biji buah alpukat formula III

Berdasarkan Tabel 3 diketahui bahwa mortalitas larva yang tertinggi yaitu pada perlakuan I dengan nilai persentase mortalitas sebesar $48 \%$. Hal ini dikarenakan pada perlakuan kontrol positif hanya digunakan ekstrak biji buah alpukat murni dan air ledeng, tanpa bahan tambahan pembentuk granul yaitu explotab dan saccharum lactis. Hasil yang sama juga diperoleh pada penelitian uji daya larvasida ekstrak biji kelengkeng, dimana kontrol positif memberikan nilai mortalitas tertinggi (Rukminingsih \& Kristiani, 2016). Persentase mortalitas larva Ae aegypti pada perlakukan I lebih tinggi dibandingkan dengan perlakukan II, III dan IV. Pada perlakuan II mengandung explotab dengan jumlah paling sedikit menghasilkan persentase mortalitas paling rendah yaitu sebesar 38,66\%, selanjutnya diikuti oleh perlakuan III dan IV. Pada perlakuan sand granules yang menghasilkan persentase mortalitas larva tertinggi yaitu pada perlakuan IV sebesar $42 \%$. Perlakuan IV merupakan formula sand granules dengan kadar Explotab sebagai bahan penghancur paling besar yaitu 4\%. Hasil tersebut dipengaruhi oleh kadar Explotab yang semakin besar, Explotab menunjukkan disintegrasi yang sangat cepat pada pembuatan granul dengan metode granulasi basah (Kaur \& Nivedita, 2016). Hasil penelitian Laksmita, 2017, menyatakan bahwa perbedaan kadar bahan penghancur berpengaruh pada waktu hancur sediaan karena semakin tinggi kadar bahan penghancur maka semakin cepat sediaan padat untuk hancur. Hal tersebut didukung oleh hasil penelitian Endriyatno, 2018, yang menyatakan bahwa Explotab dapat menurunkan waktu hancur. Kecepatan waktu hancur sediaan dikarenakan Explotab mempunyai kemampuan swelling pada air sebesar 300 kali volumenya (Rowe, et al., 2009). Mekanisme penghancuran sediaan dengan cara swelling terjadi pada saat partikel bahan penghancur bersentuhan langsung dengan media yang sesuai (pada penelitian ini media yang digunakan adalah akuades) maka kekuatan disintegran untuk menggembang meningkat, sehingga sediaan akan pecah dan zat aktif akan terlepas (Pahwa \& Nisha, 2011). Oleh karena itu dengan waktu pemaparan sand granules yang sama (24 jam) menghasilkan jumlah mortalitas larva yang berbeda, dimana pada pada perlakuan IV sediaan sand granules dengan kadar Explotab paling tinggi menghasilkan persentase mortalitas larva Ae aegypti yang lebih besar dibandingkan perlakukan II dan III. Hal ini disebabkan karena pada perlakuan IV kekuatan disintegran mengembang lebih besar, sehingga sediaan sand granules lebih cepat pecah dan zat aktif yang terkandung dalam ekstrak biji alpukat lebih mudah terlepas, dengan demikian dapat lebih banyak mematikan larva Ae aegypti. Berdasarkan Tabel 3 diketahui bahwa perbedaan kadar Explotab mempengaruhi hasil persentase mortalitas larva.

Hasil persentase mortalitas larva selanjutnya dilakukan analisis statistik menggunakan SPSS. Hasil uji statistik antar perlakuan menunjukkan bahwa data jumlah larva mati pada perlakuan I, III dan IV terdistribusi normal $(\mathrm{p}=1,000>0,05)$ sedangkan pada perlakuan II data yang dihasilkan terdistribusi tidak normal $(\mathrm{p}=0,00<0,05)$, sehingga dilakukan uji Kruskal Wallis. Berdasarkan uji Kruskal Wallis, jumlah larva mati pada perlakukan I-IV dengan perbedaan konsentrasi Explotab menunjukkan 
adanya perbedaan yang bermakna $(\mathrm{p}=0,041<0,05)$. Analisis statistik dilanjutkan dengan Mann Whitney Test yang dapat dilihat pada Tabel 4.

Tabel 4. Perbedaan Mortalitas Larva pada Setiap Perlakuan

\begin{tabular}{ccccc}
\hline \multirow{2}{*}{ Perlakuan } & \multicolumn{4}{c}{ p-value } \\
\cline { 2 - 5 } & I & II & III & IV \\
\hline I & & $0,046^{\mathrm{a}}$ & $0,05^{\mathrm{a}}$ & $0,077^{\mathrm{a}}$ \\
\hline II & $0,046^{\mathrm{a}}$ & & $0,346^{\mathrm{a}}$ & $0,72^{\mathrm{a}}$ \\
\hline III & $0,05^{\mathrm{a}}$ & $0,346^{\mathrm{a}}$ & & $0,261^{\mathrm{a}}$ \\
\hline IV & $0,077^{\mathrm{a}}$ & $0,72^{\mathrm{a}}$ & $0,261^{\mathrm{a}}$ & \\
\hline
\end{tabular}

\section{${ }^{\mathrm{a}}$ Mann Whitney Test}

Berdasarkan Tabel 4 dapat diketahui bahwa antara perlakuan I dan II serta perlakuan I dan III menghasilkan nilai signifikansi $<0,05$ yang berarti antar perlakuan terdapat perbedaan yang bermakna. Pada perlakuan I dan IV, II dan III, II dan IV serta perlakuan III dan IV menghasilkan nilai signifikansi > 0,05 yang berarti antar perlakuan berbeda tidak bermakna. Hal ini berarti konsentrasi Explotab berpengaruh pada mortalitas larva pada perlakuan I dan II, serta pada perlakuan I dan III, tetapi tidak berpengaruh pada mortalitas larva di perlakuan yang lain.

Hasil uji mortalitas larva pada Tabel 2 diketahui bahwa pada pemaparan sand granules biji alpukat selama 1 jam disetiap perlakuan (I - IV) menghasilkan nilai yang konstan yaitu tidak ada larva yang mati. Data mortalitas larva pada pemaparan sand granules selama 2 jam hingga 24 jam selanjutnya dilakukan analisis statistik menggunakan SPSS. Hasil analisis statistik dapat dilihat pada Tabel 5.

Tabel 5. Normalitas Mortalitas Larva Pada Waktu Pemaparan Sand Granules Ekstrak Biji Buah Alpukat

\begin{tabular}{ccccccc}
\hline \multirow{2}{*}{ Perlakuan } & \multicolumn{7}{c}{ Nilai Normalitas } \\
\cline { 2 - 7 } & $\mathbf{2}$ jam & 3 jam & 4 jam & $\mathbf{5}$ jam & $\mathbf{6}$ jam & $\mathbf{2 4}$ jam \\
\hline I & 0,000 & 1,000 & 1,000 & 0,000 & 1,000 & 0,000 \\
\hline II & - & 0,000 & 0,000 & 0,000 & 1,000 & 1,000 \\
\hline III & - & 0,000 & 0,000 & 1,000 & 0,000 & 0,000 \\
\hline IV & - & 0,000 & 0,000 & 0,000 & 0,000 & 0,000 \\
\hline p-value & $0,392^{\mathrm{a}}$ & $0,725^{\mathrm{a}}$ & $0,103^{\mathrm{a}}$ & $0,043^{\mathrm{a}}$ & $0,190^{\mathrm{a}}$ & $0,571^{\mathrm{a}}$ \\
\hline
\end{tabular}

\section{${ }^{\mathrm{a}}$ Kruskal Wallis Test}

Pada Tabel 5 dapat diketahui bahwa terdapat sebaran data yang tidak terdistribusi normal $<0,05$ dan terdapat data yang terdistribusi normal dengan nilai signifikansi $>0,05$. Oleh karena itu data di analisis statistik menggunakan Kruskal Wallis Test. Berdasarkan hasil Kruskal Wallis Test diketahui bahwa nilai signifikansi pada pemaparan sand granules selama 2, 3, 4, 6, dan 24 jam menghasilkan nilai signifikansi $>0,05$ sedangkan pada 5 jam pemaparan dihasil nilai signifikansi sebesar 0,043 $<0,05$. Analisis statistik dilanjutkan dengan Mann Whitney Test untuk mengetahui perbedaan mortalitas larva pada 5 jam pemaparan sand granules. Hasil analisis statistik Mann Whitney Test dapat dilihat pada Tabel 6. 
Tabel 6. Perbedaan Mortalitas Larva pada 5 Jam Pemaparan Sand Granule

\begin{tabular}{ccccc}
\hline \multirow{2}{*}{ Perlakuan } & \multicolumn{4}{c}{ p-value } \\
\cline { 2 - 5 } & I & II & III & IV \\
\hline I & & $0,099^{\mathrm{a}}$ & $0,046^{\mathrm{a}}$ & $0,043^{\mathrm{a}}$ \\
\hline II & $0,099^{\mathrm{a}}$ & & $0,105^{\mathrm{a}}$ & $0,099^{\mathrm{a}}$ \\
\hline III & $0,046^{\mathrm{a}}$ & $0,105^{\mathrm{a}}$ & & $0,637^{\mathrm{a}}$ \\
\hline IV & $0,043^{\mathrm{a}}$ & $0,099^{\mathrm{a}}$ & $0,637^{\mathrm{a}}$ & \\
\hline
\end{tabular}

${ }^{\mathrm{a}}$ Mann Whitney Test

Pada Tabel 6 diketahui bahwa perbedaan mortalitas larva antar perlakuan I dan II, II dan III, II dan IV serta perlakuan III dan IV menghasilkan nilai signifikansi > 0,05 yang berarti tidak terdapat perbedaan yang bermakna. Hasil tersebut berbeda dengan perlakuan I dan III serta perlakuan I dan IV yang menghasilkan nilai signifikansi $<0,05$ yang berarti terdapat perbedaan yang bermakna. Berdasarkan hasil analisis statistik dapat disimpulkan bahwa konsentrasi Explotab berpengaruh pada mortalitas larva pada perlakuan I dan III, serta perlakuan I dan IV di 5 jam pemaparan sand granules ekstrak biji buah alpukat, tetapi tidak berpengaruh pada mortalitas larva di perlakuan yang lain. Hal ini terjadi karena di 5 jam pemaparan sand granules ekstrak biji buah alpukat, rata-rata jumlah mortalitas larva Ae aegypti pada perlakuan I di tiap jam perlakuan jumlahnya paling tinggi dibandingkan mortalitas larva pada perlakukan II, III dan IV.

\section{KESIMPULAN}

1. Daya larvasida ekstrak biji alpukat murni dengan $\mathrm{LC}_{50} 8,87 \mathrm{mg} \cdot \mathrm{L}^{-1}$ lebih besar dari sand granules ekstrak biji alpukat.

2. Penambahan konsentrasi bahan penghancur Explotab dalam sand granules tidak berpengaruh terhadap total mortalitas larva.

\section{UCAPAN TERIMAKASIH}

Terimakasih kepada Akademi Farmasi Theresiana Semarang yang telah mendukung dan mendanai penelitian ini.

\section{DAFTAR PUSTAKA}

Agoes, G. (2012). Sediaan Farmasi Padat (SFI-6). Bandung: Institut Teknologi Bandung.

Anief, M. (2000). Ilmu Meracik Obat Teori dan Praktek. Yogyakarta: UGM Press.

Bhusnure, O. G., Gholve, S., Giram, P., Thonte, S. S., Mane, J. M., Kazi, P. A., \& Bhange, M. A. (2015). Role of Superdisintegratings in Fast Dissolving Tablets. International Journal of Pharmacy \& Pharmaceutical Research, 4(2): 263- 281.

Endriyatno, N. C. (2018). Optimasi Formula Tablet Ekstrak Daun Sirsak (Annona muricata L.) Dengan Bahan Pengikat Cmc Na Dan Penghancur Explotab Menggunakan Metode Factorial Design (Unpublished undergraduate thesis), Universitas Muhammadiyah Surakarta. Indonesia.

Jaime, J. GL. (2009). Chemical Composition, Toxicity and Larvicidal and Antifungal Activities of Persea america (Avocado) Seed Extracts. Revista da Sociedade Brasilleira de Medicina Tropical, 42(2):110-113. 
Kaur, V., \& Nivedita, M. (2016). A Review on: Importance of Superdisintegrants on Immediate Release Tablets. IJRSI, 3(2): 39-43.

Kemenkes RI. (2018). Situasi Penyakit Demam Berdarah Tahun 2017. Jakarta: Infodatin Pusat Data dan Informasi Kementerian Kesehatan Republik Indonesia.

Kemenkes RI. (2019). Nyamuk DBD Mudah Menyerang. http://www.depkes.go.id/article/print/19011400002/nyamuk-dbd-mudah-menyerang.html (Diakses pada tanggal 1 September 2019).

Laksmita, M. M. (2017). Pengaruh Perbedaan Penggunaan Bahan Penghancur Pati Pisang Kepok (Musa paradisiaca var ABB) Pregelatinasi Dan Explotab Terhadap Sifat Fisik Dan Disolusi Tablet Parasetamol, (Unpublished undergraduate thesis), Universitas Muhammadiyah Surakarta. Indonesia.

Pahwa, R. \& Nisha G. (2011). Superdisintegrant in the Development of Orally Disintegrating Tablets: A Review. International Journal of Pharmaceutical Science and Research, 2(11): 2767-2780.

Priyambodo, B. (2007). Manajemen Farmasi Industri, 121-122. Yogyakarta: Global Pustaka Utama.

Pujiastuti, A. (2003). Daya Larvasida Ekstrak Etanol dan Infusa Daging Buah Lerak (Sapindus rarak DC.) terhadap Larva Aedes aegypti (Unpublished undergraduate thesis), Universitas Sanata Dharma, Indonesia.

Pujiastuti, A., Priamsari, M. R., \& Rukminingsih, F. (2008). Sand Granules Daging Buah Lerak sebagai Larvasida Alami Pemberantas Demam Berdarah Dengue, Laporan Penelitian Dosen Muda, Akademi Farmasi Theresiana Semarang.

Rowe, R. C., Sheskey P. J., \& Quinn, M. E. (2009). Handbook of Pharmaceutical Excipients $6^{\text {th }}$ Edition. London: Pharmaceutical Press. 663-666.

Rukminingsih, F., \& Kristiani, M. (2016). Sandgranules Ekstrak Biji Kelengkeng (Euphorian longan Seed Extract) sebagai Larvasida Alami Pemberantas Demam Berdarah Dengue, Prosiding Seminar Nasional Pengembangan Sumber Daya Perdesaan dan Kearifan Lokal Berkelanjutan VI, Universitas Jenderal Soedirman.

Sembel, D. T. (2009). Entomologi Kedokteran. Yogyakarta: Penerbit Andi.

Sukowati, S. (2010). Masalah vektor demam berdarah dengue (DBD) dan pengendaliannya di Indonesia. Dalam: Pusat Data dan Surveilans Epidemiologi Kemenkes RI. Buletin Jendela Epidemiologi. Volume ke-2.

Widayanti, Y. (2001). Daya Larvasida Ekstrak Etanol dan Perasan Daun Mimba (Azadiracta indica A. Juss) Terhadap Larva Aedes aegypti (Unpublished undergraduate thesis), Universitas Sanata Dharma, Indonesia.

Widiarti., Heriyanto, B., Boewono, D.T., Widyastuti, U., Mujiono., Lasmiati. (2011). Peta Resistensi Vektor Demam Berdarah Dengue Aedes aegypti terhadap Insektisida Kelompok Organofosfat, Karbamat dan Pyrethroid di Propinsi Jawa Tengah Dan Daerah Istimewa Yogyakarta, Buletin Penelitian Kesehatan, 39(4) : 176-89. 